\title{
Effects of chemical control of Diabrotica virgifera virgifera LeConte larvae on maize using methiocarb and thiacloprid with deltamethrin
}

\author{
Efekty chemicznego zwalczania larw Diabrotica virgifera virgifera LeConte \\ na kukurydzy z wykorzystaniem metiokarbu \\ oraz tiachloprydu z deltametryną
}

Paweł K. Bereś*

\begin{abstract}
Summary
The study was carried out in 2014-2015, in Krzeczowice, south-eastern Poland, on a field of San maize (FAO 240) grown in an 8- and 9-year monoculture. Larvae of Diabrotica virgifera virgifera were controlled using two products: seed dressing containing methiocarb (Mesurol $500 \mathrm{FS}$ ) at a dose of $1.0 \mathrm{l} / 100 \mathrm{~kg}$ of seeds, and a systemic foliar insecticide containing a mixture of thiacloprid with deltamethrin (Proteus $110 \mathrm{OD}$ ) at a dose of $0.5 \mathrm{l} / \mathrm{ha}$. The tested insecticides were applied either alone or in combination. Methiocarb was applied directly before maize sowing, and thiacloprid with deltamethrin was used when maize developed 8-9 leaves, which coincided with the abundant occurrence of $D$. v. virgifera larvae on maize roots. In the years of the carried out studies on average 5.8-6.3 larvae were feeding on the root system of maize untreated with insecticide, and they caused 2.8-3.4 degree root damage on the 1-6 IOWA scale, and caused lodging in 27.5-33.2\% of plants (the goose neck symptom). The effectiveness of the seed dressing with methiocarb differed depending on the year. Methiocarb reduced the number of larvae on roots by $34.9-56.9 \%$ and lodging of plants by $33.8-53.3 \%$. Additional spraying of maize plants treated with methiocarb (Proteus 110 OD) reduced the number of larvae on roots by $39.6-53.4 \%$ and the number of lodging plants by $40.0-51.2 \%$. Thiacloprid with deltamethrin used alone for spraying did not protect plants against feeding larvae of $D$. $v$. virgifera, despite the systemic effect of this insecticide. The study revealed that other active substances have to be used to ensure the effective control of larvae in maize monocultures.
\end{abstract}

Key words: Zea mays; Western corn rootworm; seed dressing; foliar insecticide; effectiveness

\begin{abstract}
Streszczenie
Badania wykonano w latach 2014-2015, w południowo-wschodniej Polsce, w miejscowości Krzeczowice na kukurydzy odmiany San (FAO 240) uprawianej w 8- i 9-letniej monokulturze. Do zwalczania larw Diabrotica virgifera virgifera zastosowano dwa preparaty: zaprawę nasienną zawierającą metiokarb (Mesurol $500 \mathrm{FS}$ ) stosowaną w dawce 1,0 l/100 kg ziarna oraz preparat nalistny o systemicznym działaniu w roślinie zawierający mieszaninę tiachloprydu i deltametryny (Proteus 110 OD) stosowany w dawce $0,5 \mathrm{l} / \mathrm{ha}$. Testowane insektycydy aplikowano pojedynczo oraz w połączeniu ze sobą. Metiokarb aplikowano bezpośrednio przed siewem kukurydzy, natomiast tiachlopryd z deltametryną stosowano, gdy kukurydza rozwijała 8-9 liści, co zbiegało się w czasie z licznym żerowaniem larw $D$. v. virgifera na korzeniach kukurydzy. W latach badań na korzeniach roślin niechronionych chemicznie żerowało średnio 5,8-6,3 sztuk larw, które uszkodziły korzenie w stopniu 2,8-3,4 w 6-stopniowej skali IOWA, doprowadzając do wylegania łodyg u 27,5-33,2\% roślin (objaw gęsiej szyi). Skuteczność zaprawy zawierającej metiokarb była zmienna w latach badań. Jej użycie ograniczyło liczbę larw na korzeniach o 34,9-56,9\% oraz objawy wylegania u 33,8-53,3\% roślin. Dodatkowe opryskiwanie roślin zaprawionych metiokarbem preparatem Proteus 110 OD ograniczyło liczbę larw na korzeniach o 39,6-53,4\% oraz liczbę wylegających roślin o 40,0-51,2\%. Zastosowanie tylko tiachloprydu z deltametryną w postaci opryskiwania roślin nie zabezpieczało roślin przed żerowaniem larw D. v. virgifera, nawet pomimo systemicznego oddziaływania preparatu. Wykonane badania pokazały, że dla potrzeb skutecznego zwalczania larw w monokulturach kukurydzy konieczne jest stosowanie innych substancji czynnych.
\end{abstract}

Słowa kluczowe: Zea mays; stonka kukurydziana; zaprawa nasienna; insektycyd nalistny; skuteczność

\footnotetext{
Instytut Ochrony Roślin - Państwowy Instytut Badawczy

Terenowa Stacja Doświadczalna

Langiewicza 28, 35-101 Rzeszów

*corresponding author: beresp@iorpib.poznan.pl

The Polish Society of Plant Protection

The Institute of Plant Protection - National Research Institute
} 


\section{Wstęp / Introduction}

Zachodnia kukurydziana stonka korzeniowa (Diabrotica virgifera virgifera LeConte) zwana potocznie stonką kukurydzianą pochodzi z Ameryki Północnej, a do Europy została zawleczona w latach 80. dwudziestego wieku wraz z transportami lotniczymi (Bača 1994). Pierwsze wykrycie gatunku miało miejsce w Serbii w 1992 roku (Bača i wsp. 1995). Od tego roku datuje się początek ekspansji szkodnika na kontynencie europejskim, a której sprzyjały dodatkowe zawleczenia z Ameryki Północnej, jakie miały miejsce pod koniec lat 90. i na początku 21. wieku do Włoch, Francji i Anglii (Ciosi i wsp. 2008). Z uwagi na wysokie zdolności do czynnego i biernego przemieszczania się na duże odległości, w tym z wykorzystaniem środków transportu lądowego, powietrznego i wodnego, do końca 2012 roku stonka kukurydziana wystąpiła w 22 krajach europejskich (EPPO 2012).

W Polsce gatunek pojawił się po raz pierwszy w 2005 roku na obszarze województwa podkarpackiego i jako szkodnik kwarantannowy objęty został urzędowym monitoringiem, a nadzór nad jego zwalczaniem sprawowała Państwowa Inspekcja Ochrony Roślin i Nasiennictwa (Sahajdak i wsp. 2006). Zaledwie kilka miesięcy po oficjalnym wykryciu D. v. virgifera (w 2006 roku) nastąpiło gwałtowne zwiększenie zasięgu jej występowania, który objął aż 8 województw położonych w południowej i częściowo środkowej części kraju (Konefał i Bereś 2009). Była to jedna $\mathrm{z}$ najszybszych ekspansji owada obserwowana w Europie. Z kolei w latach 2007-2013 stonka kukurydziana w zależności od roku zasiedlała od 8 do 11 województw (Bereś i wsp. 2015).

D. v. virgifera jako organizm kwarantannowy w Unii Europejskiej do 2014 roku podlegała obligatoryjnemu zwalczaniu w oparciu o systematycznie aktualizowane unijne i krajowe przepisy fitosanitarne (Rozporządzenie 2014). W celu całkowitej eliminacji jej pierwszych ognisk występowania, a później dla potrzeb spowolnienia ekspansji i zapobiegania stratom $\mathrm{w}$ plonach stosowano różne metody, w tym agrotechniczne (głównie płodozmian) oraz chemiczne (Konefał i Bereś 2009).

Szczególnie dużym wyzwaniem dla rolników jest zwalczanie larw występujących w monokulturach kukurydzy, które przebywając $\mathrm{w}$ glebie są trudne do zaobserwowania, a ich żerowanie uwidacznia się dopiero w postaci stopniowego wylegania roślin na skutek uszkadzania systemu korzeniowego (Chiang 1973). Stanowią najgroźniejsze stadium rozwojowe stonki kukurydzianej i są głównym celem prowadzonych działań zwalczających w tych krajach, w których gatunek się pojawił (Kiss i wsp. 2005).

Aktualnie w Polsce, nie można w sposób bezpośredni zwalczać larw z wykorzystaniem metody chemicznej. Na przestrzeni 10 lat występowania stonki kukurydzianej w kraju, jedynie w dwóch latach istniała możliwość zastosowania insektycydów przeciwko larwom w ramach tzw. tymczasowej ich rejestracji. W 2008 roku można było użyć zaprawę nasienną Poncho Pro 600 FS (chlotianidyna), natomiast w 2010 roku insektycyd doglebowy Force 1,5 G (teflutryna) (Bereś i Konefał 2012).

Obecnie, w związku z wykreśleniem stonki kukurydzianej z listy organizmów kwarantannowych oraz częstą uprawą kukurydzy w wieloletniej monokulturze, która pozwala szkodnikowi przejść przez cykl rozwojowy, pojawiła się pilna potrzeba znalezienia skutecznego sposobu zwalczania larw na polach prowadzonych w tym uproszczeniu agrotechnicznym. W badaniach wykonanych w ramach Programu Wieloletniego Instytutu Ochrony Roślin - Państwowego Instytutu Badawczego na lata 2011-2015, dotyczących opracowania strategii zwalczania stonki kukurydzianej wykazano, że do pośredniego zwalczania stadium larwalnego można użyć zapraw nasiennych zawierających imidachlopryd oraz metiokarb, które posiadają już rejestrację w kukurydzy przeciw drutowcom, pędrakom, ploniarce zbożówce i rolnicom. W ramach tych badań uzyskano dobre efekty użycia imidachloprydu oraz nieco słabsze metiokarbu (Bereś 2013). Z chwilą jednak wprowadzenia zakazu stosowania w kukurydzy zapraw nasiennych zawierających imidachlopryd, podjęto dwuletnie badania mające na celu sprawdzenie przydatności pozostałych substancji czynnych zarejestrowanych już w kukurydzy do zwalczania larw stonki kukurydzianej (Rozporządzenie 2013).

Celem wykonanych badań była ocena efektów chemicznego zwalczania larw $D$. v. virgifera za pomoca metiokarbu oraz tiachloprydu $\mathrm{z}$ deltametryną, które to substancje czynne są zarejestrowane w kukurydzy do zwalczania ploniarki zbożówki.

\section{Materiały i metody / Materials and methods}

Badania wykonano w latach 2014-2015, w południowo-wschodniej Polsce, w Krzeczowicach, w 8- i 9-letniej monokulturze kukurydzy pastewnej odmiany San (FAO 240). Doświadczenie miało układ bloków losowanych kompletnie zrandomizowanych w czterech powtórzeniach. Kukurydzę wysiewano w trzeciej dekadzie kwietnia na poletkach o powierzchni $50 \mathrm{~m}^{2}$. W badaniu zastosowano zaprawę nasienną Mesurol 500 FS (metiokarb) stosowaną $\mathrm{w}$ dawce $1,0 \mathrm{l} / 100 \mathrm{~kg}$ ziarna oraz insektycyd nalistny o systemicznym oddziaływaniu w roślinie Proteus 110 OD (tiachlopryd + deltametryna) aplikowany w dawce $0,51 /$ ha, przy użyciu 3001 wody/ha. Wymienione preparaty stosowano zarówno pojedynczo, jak również w połączeniu.

Zaprawianie ziarna siewnego przeprowadzano bezpośrednio przed siewem kukurydzy (termin T0) w fazie rozwojowej kukurydzy BBCH 00 (Adamczewski i Matysiak 2011). Z kolei termin zastosowania insektycydu nalistnego (termin T1) przypadał w dniach: 18 czerwca 2014 roku i 16 czerwca 2015 roku w czasie, gdy kukurydza rozwijała 8-9 liści (BBCH 18-19). Termin ten ustalono w oparciu o monitoring występowania szkodnika, który wskazał, że w tym czasie licznie żerowały na korzeniach kukurydzy larwy w pierwszym i drugim stadium rozwojowym $\left(\mathrm{L}_{1} \mathrm{i}_{2} \mathrm{~L}_{2}\right)$ oraz pojawiały się pierwsze osobniki $\mathrm{w}$ trzecim $\left(\mathrm{L}_{3}\right)$, najgroźniejszym stadium larwalnym.

Ocenę rozmiaru uszkodzenia korzeni kukurydzy przez larwy wraz z ustaleniem ich liczebności przeprowadzono w pierwszej dekadzie lipca, w fazie, gdy rośliny rozwijały 4-5 kolanko (BBCH 34-35). W tym czasie na każdym 
poletku pobierano losowo po 10 roślin (razem 40 roślin z obiektu doświadczalnego). Wielkość pobieranej bryły korzeniowej wraz $\mathrm{z}$ otaczającą glebą miała szerokość $30 \mathrm{~cm}$ i głębokość $20 \mathrm{~cm}$. Bryłę korzeniową i glebę poddawano obserwacjom na obecność szkodnika. Poszukiwano larw bezpośrednio na systemie korzeniowym oraz w tkankach korzeni, a także wewnątrz korzeni podporowych i w nasadzie łodygi. Dodatkowo przesiewano na drobnooczkowym sicie glebę $\mathrm{z}$ otaczającą bryłą korzeniową i liczono wszystkie żywe larwy. Oczyszczony z gleby system korzeniowy dokładnie płukano w wodzie w celu przeprowadzenia oceny stopnia jego uszkodzenia przez larwy. Zastosowano 6-stopniową skalę IOWA, w której stopień 1 - oznaczał brak uszkodzeń, natomiast stopień 6 - wskazywał na zniszczenie trzech lub więcej podziemnych węzłów korzeni.

W październiku z każdego poletka zebrano plon ziarna. Przeliczono jego wysokość na plon przy 15\% zawartości wody oraz wyrażono w tonach z hektara.

Wyniki badań poddano ocenie statystycznej w programie STATISTICA PL v. 10.0. Wykonano analizę wariancji dla układu jednoczynnikowego według układu losowanych bloków. Istotność różnic między średnimi sprawdzano przy pomocy testu Tukeya dla $\mathrm{p}<0,05$. W tabelach wyników średnie, należące do grup jednorodnych oznaczono tą samą literą alfabetu. Skuteczność chemicznego zwalczania larw $D$. v. virgifera obliczono za pomocą wzoru Abbotta:

$$
S=\frac{(A-B) \times 100 \%}{A}
$$

$S$ - skuteczność,

$A$ - liczba roślin z objawami wylegania łodyg, średni stopień uszkodzenia korzeni, średnia liczba larw na korzeniach na obiekcie kontrolnym,

$B$ - liczba roślin z objawami wylegania łodyg, średni stopień uszkodzenia korzeni, średnia liczba larw na korzeniach na obiekcie chronionym insektycydami.

\section{Wyniki i dyskusja / Results and discussion}

Przebieg najważniejszych parametrów pogodowych w latach 2014-2015, w okresie prowadzenia badań, tj. od kwietnia do lipca przedstawiono w tabeli 1 . W obu latach, koniec kwietnia i pierwsza połowa maja charakteryzowały się dość niskimi temperaturami, które ograniczały intensywny wzrost roślin kukurydzy. Od czerwca temperatury wyraźnie wzrastały, co było widoczne zwłaszcza w 2015 roku, który był cieplejszy od wcześniejszego sezonu wegetacyjnego. W odniesieniu do opadów deszczu, bezpośrednio na początku rozwoju kukurydzy całkowita ich ilość była porównywalna w obu latach, jednak rok 2015 charakteryzował się mniejszą ilością opadów, zwłaszcza w okresie czerwca i lipca. Stwierdzono również

Tabela 1. Przebieg warunków pogodowych w Krzeczowicach, w latach 2014-2015

Table 1. Weather conditions in Krzeczowice, in 2014-2015

\begin{tabular}{|c|c|c|c|c|c|c|c|}
\hline \multirow[t]{2}{*}{$\begin{array}{l}\text { Miesiąc } \\
\text { Month }\end{array}$} & \multirow[t]{2}{*}{$\begin{array}{c}\text { Dekada } \\
\text { Ten-day period }\end{array}$} & \multicolumn{2}{|c|}{$\begin{array}{c}\text { Średnia dobowa temperatura } \\
\text { powietrza } \\
\text { Mean daily air temperature } \\
{\left[{ }^{\circ} \mathrm{C}\right]}\end{array}$} & \multicolumn{2}{|c|}{$\begin{array}{c}\text { Dobowa suma opadu deszczu } \\
\text { Mean daily rainfall sum } \\
{[\mathrm{mm}]}\end{array}$} & \multicolumn{2}{|c|}{$\begin{array}{c}\text { Średnia dobowa wilgotność } \\
\text { powietrza } \\
\text { Mean daily air humidity } \\
{[\%]}\end{array}$} \\
\hline & & 2014 & 2015 & 2014 & 2015 & 2014 & 2015 \\
\hline \multirow{4}{*}{$\begin{array}{c}\text { Kwiecień } \\
\text { April }\end{array}$} & I & 8,5 & 4,2 & 16,2 & 21,4 & 70,5 & 75,3 \\
\hline & II & 8,0 & 9,3 & 8,9 & 7,9 & 79,5 & 57,4 \\
\hline & III & 13,6 & 12,5 & 9,5 & 1,9 & 79,7 & 56,5 \\
\hline & $\begin{array}{c}\text { średnia/suma miesięczna } \\
\text { monthly mean/sum }\end{array}$ & 10,0 & 8,7 & 34,6 & 31,2 & 76,5 & 63,0 \\
\hline \multirow{4}{*}{$\begin{array}{l}\text { Maj } \\
\text { May }\end{array}$} & I & 11,6 & 13,1 & 8,2 & 30,4 & 65,5 & 70,8 \\
\hline & II & 12,8 & 13,4 & 59,8 & 7,8 & 77,2 & 60,2 \\
\hline & III & 17,3 & 12,8 & 24,3 & 54,7 & 65,5 & 81,1 \\
\hline & $\begin{array}{l}\text { średnia/suma miesięczna } \\
\text { monthly mean/sum }\end{array}$ & 13,9 & 13,1 & 92,3 & 92,9 & 69,4 & 70,7 \\
\hline \multirow{4}{*}{$\begin{array}{c}\text { Czerwiec } \\
\text { June }\end{array}$} & $\mathrm{I}$ & 17,6 & 19,5 & 3,3 & 0,0 & 70,2 & 53,5 \\
\hline & II & 16,1 & 17,9 & 12,5 & 8,0 & 64,3 & 60,5 \\
\hline & III & 16,0 & 16,4 & 32,3 & 1,1 & 66,1 & 64,4 \\
\hline & $\begin{array}{l}\text { średnia/suma miesięczna } \\
\text { monthly mean/sum }\end{array}$ & 16,5 & 17,9 & 48,1 & 9,1 & 66,8 & 59,4 \\
\hline \multirow{4}{*}{$\begin{array}{l}\text { Lipiec } \\
\text { July }\end{array}$} & $\mathrm{I}$ & 19,3 & 21,1 & 36,8 & 13,1 & 69,2 & 50,4 \\
\hline & II & 20,2 & 19,9 & 43,4 & 25,7 & 73,2 & 62,8 \\
\hline & III & 21,6 & 20,6 & 48,4 & 26,5 & 72,4 & 62,0 \\
\hline & $\begin{array}{l}\text { średnia/suma miesięczna } \\
\text { monthly mean/sum }\end{array}$ & 20,3 & 20,5 & 128,6 & 65,3 & 71,6 & 58,4 \\
\hline
\end{tabular}


W 2015 roku okresową suszę oraz zaskorupienie gleby w czerwcu i lipcu, a są to czynniki bezpośrednio wpływające na migrację larw w glebie i intensywność ich żerowania. Niewielka ilość opadów deszczu w 2015 roku miała również odzwierciedlenie w spadku wilgotności powietrza.

W 2014 roku nasilenie występowania larw stonki kukurydzianej w Krzeczowicach określono jako średnie. $\mathrm{Na}$ poletkach kontrolnych, gdzie wysiano niechroniony insektycydami materiał siewny u 33,2\% roślin stwierdzono objaw częściowego wylegania roślin spowodowany uszkodzeniem systemu korzeniowego przez larwy. Szczegółowa analiza systemu korzeniowego wykazała, że na korzeniach tych roślin żerowało średnio 5,8 sztuk larw, które uszkodziły korzenie w stopniu 3,4 w 6-stopniowej skali IOWA.

Zastosowany zabieg zaprawiania materiału siewnego kukurydzy metiokarbem wykazał średnią skuteczność W zabezpieczaniu systemu korzeniowego roślin przed larwami. Użycie tylko zaprawy nasiennej ograniczyło liczbę roślin wylegających o $53,3 \%$ w stosunku do kontroli. Na systemie korzeniowym roślin zabezpieczonych metiokarbem żerowało średnio 2,5 sztuki larw, które uszkodziły korzenie w stopniu 1,7. Efektu owadobójczego oddziaływania metiokarbu nie wzmocnił także zabieg nalistny wykonany preparatem o systemicznym działaniu w roślinie. Użycie zaprawy nasiennej, a następnie opryskiwanie roślin rozwijających 8-9 liść tiachloprydem z deltametryną, pozwoliło ograniczyć liczbę wylegających roślin o $51,2 \%$ oraz zredukować liczebność larw średnio o $53,4 \%$.

Zastosowanie $\mathrm{z}$ kolei niezaprawionego ziarna siewnego, a następnie jednokrotne opryskiwanie roślin insektycydem nalistnym, nie przyniosło żadnych wymiernych efektów zwalczania szkodnika. Uzyskana skuteczność zabiegu nie różniła się statystycznie od obiektu kontrolnego. W analizowanym roku nie stwierdzono również statystycznie istotnych różnic w plonach kukurydzy między obiektami badawczymi (tab. 2).
W 2015 roku nasilenie występowania larw stonki kukurydzianej w Krzeczowicach określono jako średnie i było nieco wyższe niż w roku wcześniejszym. Na obiekcie kontrolnym, gdzie wysiano niechroniony chemicznie materiał siewny kukurydzy, u 27,5\% roślin stwierdzono objaw częściowego wylegania roślin spowodowany uszkodzeniem systemu korzeniowego przez larwy. Szczegółowa analiza wykazała, że na systemie korzeniowym roślin kontrolnych żerowało średnio 6,3 sztuk larw, które uszkodziły korzenie w stopniu 2,8 w skali IOWA. Liczba wylegających roślin oraz stopień uszkodzenia korzeni w analizowanym roku był niższy niż we wcześniejszym sezonie wegetacyjnym, najprawdopodobniej wskutek silnego zaskorupienia gleby w okresie czerwca i lipca, co utrudniało larwom przemieszczanie się w profilu glebowym.

Wpływ warunków pogodowych był prawdopodobnie odpowiedzialny za obniżenie się efektywności chemicznego zwalczania larw z wykorzystaniem zaprawy nasiennej. Użycie metiokarbu ograniczyło w 2015 roku liczbę larw na korzeniach jedynie o $34,9 \%$. Spowodowało to, że szkodnik uszkodził na tym obiekcie korzenie w stopniu 1,9 skali IOWA, co skutkowało wyleganiem łodyg u $18,2 \%$ roślin. W analizowanym roku liczba wylegających roślin oraz średnia liczba larw na korzeniach nie różniły się statystycznie między obiektem chronionym zaprawą nasienną a poletkami kontrolnymi. Nieznacznie skuteczność metiokarbu podniosło opryskiwanie roślin preparatem nalistnym. Wskutek zastosowania zaprawy owadobójczej, a następnie wykonania zabiegu nalistnego ograniczono liczbę larw na korzeniach o 39,6\%, stopień uszkodzenia korzeni o $39,2 \%$ oraz liczbę wylegających roślin o $40 \%$.

Podobnie, jak w roku wcześniejszym, zastosowanie do zwalczania larw jedynie insektycydu nalistnego o systemicznym oddziaływaniu nie przyczyniło się do skutecznego obniżenia jego liczebności oraz szkodliwości. Uzyskane plony ziarna z obiektów badawczych nie różniły się statystycznie od kontroli (tab. 3).

Tabela 2. Efekty chemicznego zwalczania larw Diabrotica virgifera virgifera w 8-letniej monokulturze kukurydzy, w Krzeczowicach, w 2014 roku

Table 2. Effects of chemical control of Diabrotica virgifera virgifera larvae in an 8-year maize monoculture, in Krzeczowice, in 2014

\begin{tabular}{|c|c|c|c|c|c|c|c|c|c|}
\hline \multirow[t]{2}{*}{$\begin{array}{l}\text { Obiekt } \\
\text { Object }\end{array}$} & \multicolumn{2}{|c|}{$\begin{array}{c}\text { Termin } \\
\text { stosowania } \\
\text { Treatment } \\
\text { date } \\
\end{array}$} & \multicolumn{2}{|c|}{$\begin{array}{l}\text { Rośliny z objawami } \\
\text { wylegania łodyg } \\
\text { Plants with symptoms } \\
\text { of stem lodging }\end{array}$} & \multicolumn{2}{|c|}{$\begin{array}{c}\text { Średni stopień } \\
\text { uszkodzenia korzeni } \\
\text { Mean degree of damage } \\
\text { to root system }\end{array}$} & \multicolumn{2}{|c|}{$\begin{array}{c}\text { Średnia liczba larw na } \\
\text { systemie korzeniowym } \\
\text { Mean number of larvae } \\
\text { on root system }\end{array}$} & \multirow[t]{2}{*}{$\begin{array}{l}\text { Plon } \\
\text { Yield } \\
\text { [t/ha] }\end{array}$} \\
\hline & T0 & $\mathrm{T} 1$ & {$[\%]$} & $\mathrm{AB}$ & $\begin{array}{l}\text { skala }- \text { scale } \\
\text { IOWA }\end{array}$ & $\mathrm{AB}$ & $\begin{array}{c}{[\text { szt. }]} \\
\text { [pcs insects] }\end{array}$ & $\mathrm{AB}$ & \\
\hline Kontrola - Control & - & - & $33,2 \mathrm{a}$ & - & $3,4 \mathrm{a}$ & - & $5,8 \mathrm{a}$ & - & $10,2 \mathrm{a}$ \\
\hline Mesurol 500 FS & + & - & $15,5 \mathrm{bc}$ & 53,3 & $1,7 \mathrm{bc}$ & 50,0 & $2,5 \mathrm{bc}$ & 56,9 & $10,5 \mathrm{a}$ \\
\hline Proteus 110 OD & - & + & $31,7 \mathrm{a}$ & 4,5 & $3,5 \mathrm{a}$ & $-2,4$ & $5,4 \mathrm{a}$ & 6,9 & $9,8 \mathrm{a}$ \\
\hline $\begin{array}{l}\text { Mesurol } 500 \mathrm{FS}+ \\
\text { Proteus } 110 \mathrm{OD}\end{array}$ & + & + & $16,2 \mathrm{bc}$ & 51,2 & $1,9 \mathrm{bc}$ & 44,1 & $2,7 \mathrm{bc}$ & 53,4 & $10,4 \mathrm{a}$ \\
\hline
\end{tabular}

$\mathrm{AB}$ - skuteczność według wzoru Abbotta - effectiveness according to Abbott's formula

Średnie oznaczone tą samą literą nie różnią się na poziomie istotności $\mathrm{p}<0,05$ według testu Tukeya - Mean values marked with the same letter do not differ significantly $\mathrm{p}<0.05$ according to Tukey's test 
Tabela 3. Efekty chemicznego zwalczania larw Diabrotica virgifera virgifera w 9-letniej monokulturze kukurydzy, w Krzeczowicach, w 2015 roku

Table 3. Effects of chemical control of Diabrotica virgifera virgifera larvae in an 9-year maize monoculture, in Krzeczowice, in 2015

\begin{tabular}{|c|c|c|c|c|c|c|c|c|c|}
\hline \multirow[t]{2}{*}{$\begin{array}{l}\text { Obiekt } \\
\text { Object }\end{array}$} & \multicolumn{2}{|c|}{$\begin{array}{c}\text { Termin } \\
\text { stosowania } \\
\text { Treatment } \\
\text { date }\end{array}$} & \multicolumn{2}{|c|}{$\begin{array}{l}\text { Rośliny z objawami } \\
\text { wylegania łodyg } \\
\text { Plants with symptoms } \\
\text { of stem lodging }\end{array}$} & \multicolumn{2}{|c|}{$\begin{array}{c}\text { Średni stopień } \\
\text { uszkodzenia korzeni } \\
\text { Mean degree of damage } \\
\text { to root system }\end{array}$} & \multicolumn{2}{|c|}{$\begin{array}{c}\text { Średnia liczba larw na } \\
\text { systemie korzeniowym } \\
\text { Mean number of larvae } \\
\text { on root system }\end{array}$} & \multirow[t]{2}{*}{$\begin{array}{l}\text { Plon } \\
\text { Yield } \\
{[\mathrm{t} / \mathrm{ha}]}\end{array}$} \\
\hline & T0 & $\mathrm{T} 1$ & {$[\%]$} & $\mathrm{AB}$ & $\begin{array}{l}\text { skala - scale } \\
\text { IOWA }\end{array}$ & $\mathrm{AB}$ & $\begin{array}{c}\text { [szt.] } \\
\text { [pcs insects] }\end{array}$ & $\mathrm{AB}$ & \\
\hline Kontrola - Control & - & - & $27,5 \mathrm{a}$ & - & $2,8 \mathrm{a}$ & - & $6,3 \mathrm{a}$ & - & $9,3 \mathrm{a}$ \\
\hline Mesurol 500 FS & + & - & $18,2 \mathrm{a}$ & 33,8 & $1,9 \mathrm{bc}$ & 32,1 & $4,1 \mathrm{a}$ & 34,9 & $9,7 \mathrm{a}$ \\
\hline Proteus 110 OD & - & + & $25,7 \mathrm{a}$ & 6,5 & $2,6 \mathrm{a}$ & 7,1 & $6,1 \mathrm{a}$ & 3,1 & $9,5 \mathrm{a}$ \\
\hline $\begin{array}{l}\text { Mesurol } 500 \mathrm{FS}+ \\
\text { Proteus } 110 \text { OD }\end{array}$ & + & + & $16,5 \mathrm{~b}$ & 40,0 & $1,7 \mathrm{bc}$ & 39,2 & $3,8 \mathrm{~b}$ & 39,6 & $10,3 \mathrm{a}$ \\
\hline
\end{tabular}

$\mathrm{AB}$ - skuteczność według wzoru Abbotta - effectiveness according to Abbott's formula

Średnie oznaczone tą samą literą nie różnią się na poziomie istotności $\mathrm{p}<0,05$ według testu Tukeya - Mean values marked with the same letter do not differ significantly $\mathrm{p}<0.05$ according to Tukey's test

Wykonane badania pokazały zmienną skuteczność zaprawy nasiennej zawierającej metiokarb w ograniczaniu liczebności larw D. v. virgifera na korzeniach kukurydzy, która w obu latach badań kształtowała się na poziomie 34,9-56,9\%. Skuteczność tą należy uznać za niewystarczającą do obniżenia zagrożenia ze strony gatunku, co miało odzwierciedlenie $\mathrm{w}$ jego szkodliwości dla roślin. Uzyskana skuteczność metiokarbu w redukowaniu liczby larw jest niższa od tej uzyskanej przez autora $\mathrm{w}$ latach 2010-2012 w 4-6-letniej monokulturze, a która kształtowała się średnio na poziomie 69,4\% (Bereś 2013). Możliwym powodem spadku skuteczności badanej zaprawy w zwalczaniu szkodnika obok wpływu pogody mogła być również większa liczebność larw związana z 8-9-letnią uprawą kukurydzy w monokulturze. Skuteczność metiokarbu tylko nieznacznie zwiększyło opryskiwanie roślin insektycydem nalistnym o systemicznym oddziaływaniu, co zaobserwowano tylko w 2015 roku.

W odniesieniu do insektycydowych zapraw nasiennych, zastosowanie w ochronie kukurydzy przed larwami stonki kukurydzianej ma głównie imidachlopryd, klotianidyna oraz tiametoksam (van Rozen i Ester 2010). W badaniach Ripka i wsp. (2007) wykonanych na Węgrzech, zastosowanie tych trzech substancji czynnych pozwalało obniżyć stopień uszkodzenia systemu korzeniowego przez larwy, jednak nie chroniło ich całkowicie przed żerowaniem $D$. v. virgifera. Do podobnych konkluzji prowadziły badania Beresia (2013) z zastosowaniem imidachloprydu i metiokarbu. W literaturze światowej, poza wcześniejszymi badaniami autora, brakuje informacji o oddziaływaniu metiokarbu na stonkę kukurydzianą, co może wynikać z niewielkiej przydatności tej substancji czynnej do zwalczania szkodnika.

Van Rozen i Ester (2010) uważają, że zastosowanie zapraw nasiennych powinno być rekomendowane w sytuacjach, kiedy liczebność stonki kukurydzianej jest niewielka. Przytaczani autorzy wskazują również, że zaprawy nasienne służą raczej do zabezpieczania systemu korzeniowego roślin przed silniejszymi uszkodzeniami, a nie są efektywnym narzędziem do ograniczania populacji szkodnika. Boriani i wsp. (2006) uważają, że zwykle w warunkach wysokiej liczebności larw D. v. virgifera, zaprawy nasienne nie gwarantują skutecznego zabezpieczenia systemu korzeniowego roślin.

W większości krajów opanowanych przez stonkę kukurydzianą, do zwalczania jej larw wykorzystuje się insektycydy doglebowe aplikowane przed lub posiewnie, zawierające m.in. bifentrynę, karbofuran, teflutrynę, chlorpiryfos oraz fipronil (van Rozen i Ester 2010). Insektycydy doglebowe aplikowane $\mathrm{w}$ ten sposób charakteryzują się wysoką skutecznością w zwalczaniu larw D. v. virgifera (Furlan i wsp. 2006; Pilz i wsp. 2009; Florian i wsp. 2011).

W praktyce nie stosuje się do zwalczania larw stonki kukurydzianej zabiegów nalistnych z użyciem preparatów systemicznych. Ma to potwierdzenie w wykonanych badaniach, w których stwierdzono niemal brak różnic w liczebności i szkodliwości larw między kontrolą a poletkami jednokrotnie opryskiwanymi tiachloprydem $\mathrm{z}$ deltametryną. Pomimo systemicznego oddziaływania badanego insektycydu $\mathrm{w}$ roślinie, nawet przy stosunkowo niewielkich rozmiarach opryskiwanych roślin, koncentracja obu substancji w tkankach musiała być na tyle mała, że nie wywołała pozytywnego efektu owadobójczego.

\section{Wnioski / Conclusions}

1. Zaprawa nasienna zawierająca metiokarb tylko częściowo pozwalała redukować liczebność oraz szkodliwość larw $D$. v. virgifera, co nie pozwalało skutecznie zabezpieczyć korzeni kukurydzy.

2. Użycie obok metiokarbu zabiegu opryskiwania roślin mieszaniną tiachloprydu $\mathrm{z}$ deltametryną tylko $\mathrm{w}$ jednym roku badań pozwoliło nieznacznie zwiększyć oddziaływanie zaprawy nasiennej na larwy.

3. Insektycyd nalistny o systemicznym oddziaływaniu nie pozwalał zabezpieczyć korzeni kukurydzy przed żerowaniem stonki kukurydzianej.

4. Dla potrzeb skutecznego ograniczania larw D. v. virgifera na plantacjach kukurydzy prowadzonych w kilkuletniej monokulturze konieczne jest wykorzystanie innych substancji czynnych, w tym tych, które z powodzeniem stosowane są w innych krajach. 


\section{Literatura / References}

Adamczewski K., Matysiak K. 2011. Kukurydza. [Maize]. s. 27-30. W: „Klucz do określania faz rozwojowych roślin jednoi dwuliściennych w skali BBCH". [Compendium of growth stage identification keys for mono- and dicotyledonous plants]. Wyd. III. Instytut Ochrony Roślin, Poznań, 132 ss.

Bača F. 1994. New member of the harmful entomofauna of Yugoslavia Diabrotica virgifera virgifera LeConte (Coleoptera, Chrysomelidae). Zaštita Bilja 45: 125-131.

Bača F., Camprag D., Keresi T., Krnjajic S., Manojlovic B., Sekulic R., Sicev I. 1995. Kukuruzna zlatica Diabrotica virgifera virgifera Le Conte. Drustvo za Zaštitu Bilja Srbije, Belgrade: 1-112.

Bereś P.K. 2013. Studium nad doskonaleniem integrowanej ochrony kukurydzy przed zachodnią kukurydzianą stonką korzeniową (Diabrotica virgifera virgifera LeConte) i omacnicą prosowianką (Ostrinia nubilalis Hbn.). [Study on the improvement of integrated maize protection against the Western corn rootworm (Diabrotica virgifera virgifera LeConte) and the European corn borer (Ostrinia nubilalis Hübner)]. Rozprawy Naukowe Instytutu Ochrony Roślin - PIB 29, 183 ss.

Bereś P.K., Konefał T. 2012. Stonka kukurydziana w Polsce - występowanie oraz metody zwalczania. [Western corn rootworm in Poland - occurrence and control methods]. Wieś Jutra 3-4: 58-63.

Bereś P.K., Sosnowska D., Fiedler Ż., Drzewiecki S., Konefał T. 2015. Zachodnia kukurydziana stonka korzeniowa (Diabrotica virgifera virgifera LeConte) - występowanie, biologia, szkodliwość oraz strategia zwalczania. [Western corn rootworm occurrence, biology, harmfulness and control strategy]. Instytut Ochrony Roślin - PIB, Poznań, 44 ss.

Boriani M., Agnosti M., Kiss J., Edwards C.R. 2006. Sustainable management of the western corn rootworm, Diabrotica virgifera Le Conte (Coleoptera: Chrysomelidae), in infested areas: experiences in Italy, Hungary and the USA. Bulletin OEPP/EPPO Bulletin 36: 531-537.

Chiang H.C. 1973. Bionomics of the northern and western corn rootworms. Annual Review of Entomology 18 (1): 47-72.

Ciosi M., Miller N.J., Kim K.S., Giordano R., Estoup A., Guillemaud T. 2008. Invasion of Europe by the western corn rootworm, Diabrotica virgifera virgifera: multiple transatlantic introductions with various reductions of genetic diversity. Molecular Ecology 17: 3614-3627.

EPPO 2012. Present situation of Diabrotica virgifera virgifera in Europe (2012). www.eppo.int/QUARANTINE/special_topics/ Diabrotica_virgifera/diabrotica_virgifera.htm [Accessed: 10.03.2016].

Florian T., Oltean I., Bunescu H., Florian C.V., Todoran C.F., Bodis I. 2011. Results obtained in control of Diabrotica virgifera virgifera larvae. Research Journal of Agricultural Sciences 43 (2): 40-43.

Furlan L., Canzi S., Di Bernardo A., Edwards C.R. 2006. The ineffectiveness of insecticide seed and planting-time soil insecticides as Diabrotica virgifera virgifera LeConte population suppressors. Journal of Applied Entomology 130 (9-10): 485-490.

Kiss J., Komáromi J., Bayar K., Edwards C.R., Hatala-Zsellér I. 2005. Western corn rootworm (Diabrotica virgifera virgifera LeConte) and the crop rotation systems in Europe. p. 189-220. In: "Western Corn Rootworm: Ecology and Management" (S. Vidal, U. Kuhlmann, C.R. Edwards, eds.). CABI Publishing, Wallingford, Oxfordshire, United Kingdom, 310 pp.

Konefał T., Bereś P.K. 2009. Diabrotica virgifera Le Conte in Poland in 2005-2007 and regulations in the control of the pest in 2008. Journal of Plant Protection Research 49 (1): 129-134.

Pilz C., Keller S., Kuhlman U. 2009. Comparative efficacy assessment of fungi, nematodes and insecticides to control western corn rootworm larvae in maize. BioControl 54 (5): 671-684.

Ripka G., Hegyi T., Kara B., Tóth B., Vasas L., Vörös G. 2007. Control of western corn rootworm larvae in maize using seed treatments (three years of Pioneer project). IWGO - Newsletter 28 (1): 61-62.

Rozporządzenie 2013. Rozporządzenie wykonawcze Komisji (UE) NR 485/2013 z dnia 24 maja 2013 r. zmieniające rozporządzenie wykonawcze (UE) $\mathrm{nr}$ 540/2011 w odniesieniu do warunków zatwierdzania substancji czynnych: klotianidyna, tiametoksam i imidachlopryd oraz zabraniające stosowania i sprzedaży nasion zaprawionych środkami ochrony roślin zawierającymi te substancje czynne (Dz. Urz. UE z dnia 24.05.2013 r., L 139/12, tom 56).

Rozporządzenie 2014. Rozporządzenie Ministra Rolnictwa i Rozwoju Wsi z dnia 24 kwietnia 2014 r. uchylające rozporządzenie w sprawie zwalczania i zapobiegania rozprzestrzenianiu się zachodniej kukurydzianej stonki korzeniowej (Dz. U. z 30.05.2014 r., poz. 707).

Sahajdak A., Bereś P.K., Konefał T. 2006. Diabrotica virgifera Le Conte - a new threat to maize crops in Poland and measures taken against the pest. Journal of Plant Protection Research 46 (2): 157-161.

van Rozen K., Ester A. 2010. Chemical control of Diabrotica virgifera virgifera LeConte. Journal of Applied Entomology 134 (5): 376-384. 